\section{CarakaTani \\ Journal of Sustainable Agriculture \\ ISSN 2613-9456 (Print) 2599-2570 (Online)}

\title{
First Morphological Detection of Non-Quarantine Pest Causing Banana Wilt in Morotai Island
}

\author{
Arief Widyantoro* and Artini \\ Plant Quarantine Section of Ternate, Indonesian Agricultural Quarantine Agency (IAQA), \\ North Maluku, Indonesia \\ ${ }^{*}$ Corresponding author: widyantoro.arief@yahoo.com
}

\begin{abstract}
There are two symptoms of wilting in banana plants that have been widely known, namely fusarium wilt and bacterial wilt. The symptoms of banana wilt usually are attributed to pathogenic fungi. Wilting symptoms on the leaves are usually accompanied by leaf spot, leaf streak, leaf speckle and anthracnose. Recent quarantine pest reports have found the symptoms of banana wilt in Morotai Island, Indonesia. The pathogens attack many local cultivars of banana plants including Mas, Ambon, Kepok and Nangka. The study aimed to establish the morphological characters of the pathogens that cause banana wilt. Descriptive research began with the sampling of diseased symptomatic leaves, field data reports and identification of pathogenic morphological characters in the laboratory. The variable observed were the disease symptoms, color and shape of mycelia, conidia, kinds of the pathogens and their growth on agar medium. The results showed that there was no quarantine pest on the symptomatic banana samples. There were two non-quarantine pests that had been identified, i.e Fusarium oxysporum causing fusarium wilt and Cladosporium musae causing leaf speckle.
\end{abstract}

Keywords: fusarium wilt; leaf speckle; leaf spot; quarantine pest

Cite this as: Widyantoro, A., \& Artini. (2020). First Morphological Detection of Non-Quarantine Pest Causing Banana Wilt in Morotai Island. Caraka Tani: Journal of Sustainable Agriculture, 35(2), 308-316. doi: http://dx.doi.org/10.20961/carakatani.v35i2.41692

\section{INTRODUCTION}

First detection and identification of quarantine pest in banana plantations are rarely done especially in the islands. Banana plants are rarely cultivated by monoculture; the plants are usually grown as intercrops. Nevertheless, banana is the leading commodity in each region. The destruction of banana plantains in North Maluku was caused by the lack of study on pathogens before the land was used for planting. The impact of diseases on crop performance depends on the first identification, which is determined by the morphological and physiological characteristics of pathogens and their interaction with plant host and environmental conditions (Martinelli et al.,
2014). Banana production centers such as Australia, Thailand and Taiwan have been mapped in the geographical distribution of pathogen before the development of banana plantain begins, so that the status of pest attacks in these area can be monitored. Early detection can support sustainable agriculture because the plant pathogens of today are far more targeted, tested, regulated, proven to be both environmentally safe and efficient than over before (Nasir et al., 2005).

The average total production of bananas in North Maluku Province reached of 4,264.90 tons in 2018, spreading in Morotai Island, East Halmahera and South Halmahera (BPS-Statistics of Maluku Utara Province, 2018). This was a dramatic decrease from 2017, which reached

\footnotetext{
* Received for publication May 17, 2020

Accepted after corrections July 29, 2020
} 
8,226.40 tons (BPS-Statistics of Maluku Utara Province, 2017). Banana production decline reached $48 \%$ in the last two years of total production in North Maluku. The most drastic decline occurred in the Morotai Island Region, 61.3 tons in 2016 and in the following years, no data of commodities were reported (DISTAN, 2018). Morotai Island is located east of Wallace's Line, so it has a fairly high diversity of bananas. This island is one of the cultivated centers of banana in Indonesia. There are 24 accessions of bananas and four wild species (plantain) in Maluku (Edison et al., 1997). In particular location (Hendaru et al., 2017), seven cultivars of banana in North Maluku have been identified i.e Mas, Gohu, Jarum, Galela, Mulu Bebe, Tembaga and Bunga. Most of them are classified into Musa acuminata AAA, except Gohu (M. paradisiaca $\mathrm{ABB})$.

There are many factors that influence the total decrease of banana production, including cultivation, environmental changes and also pest and diseases distribution. Ambon cultivar $(M$. acuminata AAA) and Kepok cultivar ( $M$. paradisiaca $\mathrm{ABB}$ ) were susceptible to wilt disease in Maluku attributed to pathogens. Some reports indicate different reactions of several cultivars to fungal pathogen infection on banana plants. The diseases caused by pathogens in banana plants are not always directly observed because the timing of symptoms is unpredictable. Some fungal diseases of bananas across the world were reported with specific names i.e Black Sigatoka (Tushemereirwe et al., 2011; Yonow et al., 2019), Panama disease, Septoria leaf spot, Cordana leaf spot, Fusarium wilt (Jones, 2000) and Cigar end rot (Amani and Avagyan, 2014).

Mas cultivar (M. acuminata AA) and Ambon cultivar were usually susceptible to Fusarium wilt (Widyantoro et al., 2020). Kepok and Nangka cultivars (M. acuminata x balbisiana $\mathrm{AAB}$ ) were susceptible to leaf spot (Sahlan, 2003). Bacterial and pathogenic fungi were the most often found in banana plants. According to Semangun (2007), the reports of bacterial wilt disease were found earlier and become an important disease spreading in several locations in Papua, Sulawesi, Maluku, especially in Central Maluku. There were currently no reports of disease progression caused by pathogenic fungi in Morotai Island. The pathogens could show the similar symptoms on plant host (Soesanto et al., 2013). Some important fungi on bananas include Fusarium wilt caused by
Fusarium oxysporum (Ploetz, 1988), leaf spot and leaf speckle caused by Mycosphaerella, Curvularia and Cladosporium (Crous et al., 2005) and anthracnose caused by Colletotrichum musae (Abd-Elsalam et al., 2010).

The International Standard on Phytosanitary Measures (ISPM) Number 16 regulating nonquarantine pest, concept and application has been adopted, describing the plant destructing organisms on agricultural commodity. Several of non-quarantine pests can cause an extremely negative impact on several plantations, even though these pests were introduced in to the area or island a long time ago. In this case, specific management measures can be defined and the pest target have to be immediately detected during the inspections of growing crops. In Indonesia, historically wilt symptoms on banana plants are associated with several pathogens (Hadiwiyono, 2011). The diseases related to fungi usually tend to spread quickly to other plants (Al-Jaradi et al., 2018).

The International Plant Protection Convention (IPPC) defines that quarantine pest is a pest that has potential economic importance to the endangered area, but it has not been widely distributed and being officially controlled (FAO, 2016). According to Quarantine Pests Regulation based on the Minister of Agriculture Number 31 year 2018, there is a quarantine pest target needed to be wary of disease spreading. One of the important pathogens in banana plants is Mycosphaerella fijiensis, which is still limitedly distributed in Indonesia (EPPO, 2011). Based on the Quarantine Pest List Report, M. fijiensis is a quarantine-destroying organism, whose population and spread are very fast in Sumatra Island (IAQA, 2018). However, non-quarantine pests from other groups are also important to be identified even though their presence in Indonesia has been settled for a long time and there have been several methods to control them.

The present evaluation of non-quarantine pest status of banana wilt disease only focuses on banana seedlings (suckers or originated from tissue culture). Also, once the disease is established, it can spread within plantations in soil on farm machinery so that it can spread from one location to other location with modern planting material. Ocean is a physical barrier to the spread of the plant disease that has been breached by the rapid transportation of people. This is the first report of occurrences of these diseases in banana 
plants in Morotai Island. Therefore, the entry and release of host plants are regulated in the territory of the importing contracting party. Early detection is necessary to be done on banana plants that shows the symptoms of wilting. The research aimed to study the morphological characteristics of pathogen that cause banana wilt in the field.

\section{MATERIALS AND METHOD}

\section{Place and wilt disease distribution}

This research was conducted at Plant Quarantine Laboratory of Ternate, Agricultural Quarantine Agency, North Maluku, Indonesia. Symptomatic banana Ambon and Kepok cultivar leaf samples were taken from smallholder plantations in Morotai Island during the Quarantine Pests Monitoring Program in North Maluku. The banana leaf sampling was done in North Morotai Regency $\left(02^{\circ} 25^{\prime} 39.9^{\prime \prime}\right.$ North Latitude [NL]; 128 $41^{\prime} 20.4^{\prime \prime}$ East Longitude [EL], South Morotai Regency $\left(02^{\circ} 05^{\prime} 33.5^{\prime \prime}\right.$ NL; $128^{\circ} 20^{\prime} 39.5^{\prime \prime}$ EL) and East Morotai Regency (02 $03^{\circ} 45.3^{\prime \prime} \mathrm{NL} ; 128^{\circ} 30^{\prime 22.7 " ~ E L) . ~}$

\section{Pathogen identification and symptoms disease}

The symptomatic banana leaf surfaces were sterilized using $70 \%$ alcohol for 4-5 minutes and then rinsed on sterile distilled water for 10 minutes. Leaf samples were dried with tissue paper. Portions of the leaves with the symptoms were selected and cut $0.5 \mathrm{~cm}^{2} \times 0.5 \mathrm{~cm}^{2}$. Pieces of the leaves sample were plated into agar medium PDA-L (potato-dextrose agar $+10 \%$ lactic acid). Plates were incubated for 5-7 days at $28^{\circ} \mathrm{C}$. Isolates were examined for conidiophores under a dissection microscope. Segments $\left(0.5 \mathrm{~cm}^{2} \mathrm{x}\right.$ $0.5 \mathrm{~cm}^{2}$ ) of banana leaf were dissected from the lesion margins. Each piece of banana leaf was placed on wet filter paper in a petri dish and incubated with a temperature of $23^{\circ} \mathrm{C}$ for 5 days. A total of 9 petri dishes, each of which containing $20 \mathrm{~mL}$ of PDA medium, were used in this test. The methods of visual observation and pathogenicity test on leaf of isolated pathogen were applied by comparing them with the presence of conidiophores and necrosis on the leaf surface.

\section{Morphology and growth of pathogenic colony}

Single-celled conidia were picked and incubated for 5 days on PDA medium. The morphological characteristics of the fungus were identified by observing the color and shape of the mycelia in cultured media. The shapes of conidia were observed by taking a small number of fungal colonies on culture media placed on objects glass and dropped with sterile distilled water and then covered with glass. Colony colors were determined by observing the upper surfaces of the colonies. The isolates were observed under an electron microscope and compared with a literature study according to Samson et al. (2004) and CABI CPC Compendium. The selected isolates were reproduced and stored in PDA for stock culture. The propagation of isolates was done by taking a small number of colonies using a cork borer with a diameter of $0.5 \mathrm{~cm}$ placed in the middle of the cultured media. The growth rates were estimated after $1,3,5,7$ and 9 days of incubation at $25^{\circ} \mathrm{C}$. The longest and shortest colony diameters were measured by calipers.

\section{RESULTS AND DISCUSSION}

\section{Disease distribution}

Banana wilt caused by fungal pathogens has been known to spread in Indonesia (Table 1). The first report of disease discovery in a crop was usually identified by more than one pathogen. The wilt disease, known as Panama wilt, first attacked Cavendish and Abaca, reported by Booth (1971). The main hosts of Fusarium wilt pathogens in Indonesia were Ambon (AAA), Kepok (ABB) and Raja (AAB) cultivars (Jayatri et al., 2018). Two lethal diseases of bananas known appeared recently in Timika, Papua were caused by bacterial wilt and Fusarium oxysporum fungus (Davis et al., 2000). The pathogens were disseminated by fruits, seeds, suckers, soils and cultivation tools (Buddenhagen, 2009).

Table 1. The distribution of pathogens that cause banana wilt in Indonesia

\begin{tabular}{llcc}
\hline \multicolumn{1}{c}{ Common name } & \multicolumn{1}{c}{ Pathogen } & Status*) & Geographical distribution \\
\hline Leaf spot $^{1)}$ & Mycosphaerella fijiensis & Quarantine pest & Sumatra \\
Fusarium wilt $\mathrm{t}^{2)}$ & Fusarium oxysporum & Non-quarantine pest & Java, Sumatra, Bangka, Borneo \\
Leaf speckle $^{3)}$ & Cladosporium musae & Non-quarantine pest & Sumatra, Borneo \\
\hline
\end{tabular}

Note: ${ }^{\left.1,{ }^{*}\right)}$ Indonesian Agricultural Quarantine Agency (2018): Pests List Report, ${ }^{2)}$ Wibowo et al. (2011), ${ }^{3)}$ Sahlan (2003) 
The symptoms of wilt disease on bananas usually refer to different pathogens. In addition to the widely known $F$. oxysporum distribution in Central Java, Lampung (Sumatra) and Borneo, there were notable pathogens in Indonesia including $M$. fijiensis and $C$. musae. Both of these pathogens attack banana plants with almost the same symptoms. M. fijiensis is a quarantine pest, while $C$. musae is non-quarantine pest, although it is a family of Mycosphaerella. Leaf speckle caused by $C$. musae syn $C$. freckle was reported by Stover (1972) in most banana growing regions. Leaf spot, known Black Sigatoka, is one of the most important foliar diseases of banana in Uganda that was surveyed by Tushemereirwe et al. (2011). Pathogens can attack bananas both simultaneously and independently with different intensity (Satyanarayana et al., 2017). This is what causes symptoms of disease in the field almost the same marked by the appearance of speckles and spots on the leaves. Wilt disease with more specific leaf speckles caused by $C$. musae being endemic in Borneo and leaf spot caused by
M. fijiensis being endemic in North Sumatra. Fusarium wilt status and geographical distribution were reported by Riska et al. (2012) in West Sumatra, Borneo and Sulawesi.

\section{Fungi identification and symptoms of disease}

Fusarium wilt symptoms were seen along the edges of young leaves like vein clearing. The banana wilt started drooping of the older lower leaves, defoliation, marginal necrosis and plant death (Figure 1A). Chlorotic spot appeared on the abaxial surface of leaf. Severely infected plants were seen pseudo-browning when the pseudostems were cut transversely. Nasir et al. (2003) added that the general symptoms of Fusarium wilt showed a typical appearance of yellowing along the edge of the leaf until all plants die. The same leaf showed the symptoms of brown disease spotted on the older leaves. This symptom was obtained by Surridge et al. (2003) that there are small patches of dark brown to black on the leaves. Soesanto et al. (2013) supported that spotting symptoms generally appear on the older leaves.

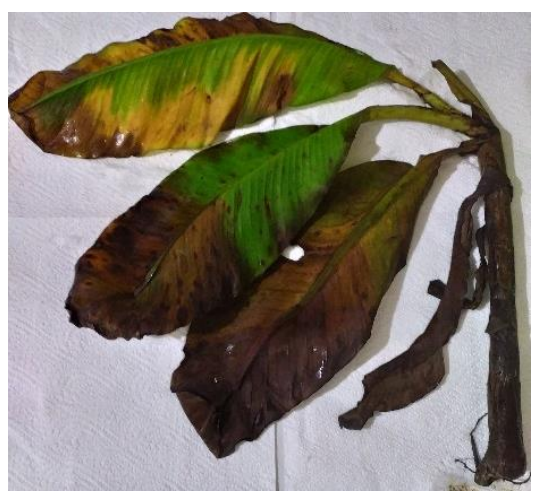

A.

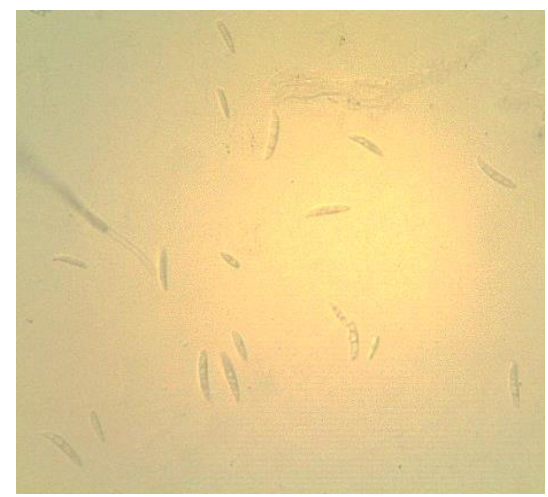

D.

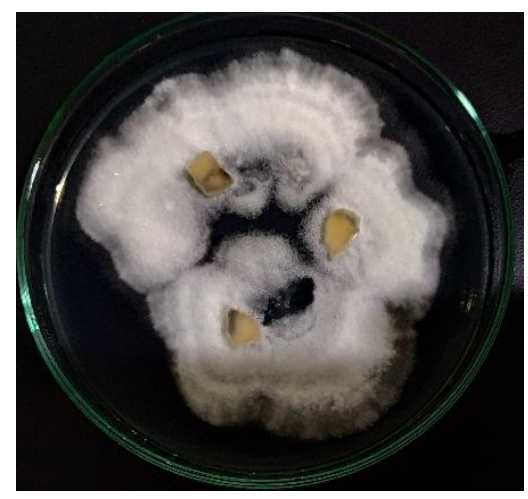

B.

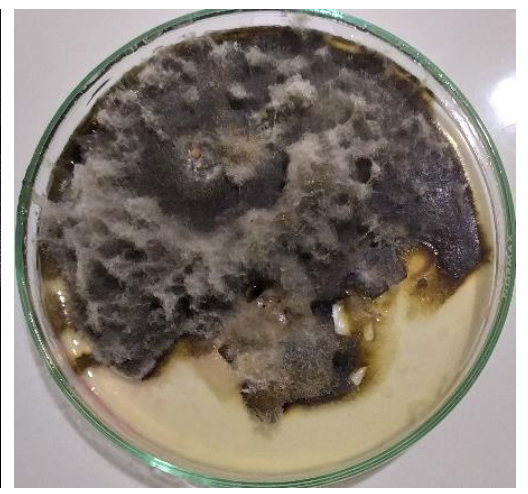

C.

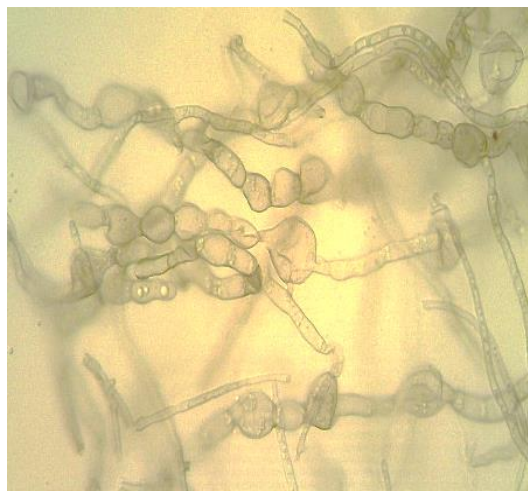

E.

Figure 1. Morphological appearance: (A) Symptoms produced by pathogens, (B) Fusarium oxysporum colony in PDA, (C) Cladosporium musae colony in agar medium, (D) F. oxysporum and (E) C. musae conidia, scale bar indicating $10 \mu \mathrm{m}$ 
There were several fungus colonies appearing on agar culture media at 5 days after isolation (DAI). The colonies suspected to be the targets of pathogens were sub-cultured by a single spore method and labeled. Two species of pathogen were isolated from the leaves of infected banana plants identified as $F$. oxysporum and $C$. musae. The test results showed the morphological appearance of $F$. oxysporum was marked with white hyphae like a cotton, while $C$. musae was black like a cotton on cultured media (Figure 1B and Figure 1C). In this study, the target of quarantine plant pests based on Indonesian Agricultural Quarantine Agency Regulation was M. fijiensis, but after in vitro test was carried out, the pests were not detected infecting any banana plants. In the initial pathogenicity testing, conidia were not found until 5 DAI even though leaf samples showed color changes based on the appearance of symptoms. Ferraez et al. (2008) added that conidia of $M$. fijiensis develops after 5 DAI, which has been marked by symptomatic changes in leaf color.

\section{Morphology and growth of pathogenic colonies}

The $F$. oxysporum colonies were white and the mycelia were insulated like a cotton on agar medium (Table 2). Some reports showed that $F$. oxysporum colonies were yellow, pink and purple on PDA from macroscopic observation. Macroconidia and microconidia attached to conidiophores. A macroconidia consists of 3-5 septat. Both ends of the macroconidia were tapered like a crescent so that a common feature of the Fusarium oxysporum appeared (Leslie and Summerell, 2006). F. oxysporum were included in Hypomycetes class, Hyphales (Moniliales) order and Tuberculariaceae family. The general characteristics of the Hypomycetes were the formation and fully development of mycelium (Seifert and Gams, 2011).

Table 2. Morphological characteristic of pathogens accompanying wilt symptoms

\begin{tabular}{clcc}
\hline No. & \multicolumn{1}{c}{ Characters } & (Isolate code:PM001) & (Isolate code: PM004) \\
Fusarium oxysporum & Cladosporium musae \\
\hline 1. & Parts of symptomatic banana & Leaf, pseudostem & Leaf \\
2. & Colony color & White & Black \\
3. & Colony diameter at 7 DAI $(\mathrm{cm})$ & 4.07 & 4.85 \\
4. & Shape of mycelia & Like cotton & Like cotton \\
5. & Conidia & & $(*)$ \\
& a. Macroconidia & & \\
& - Shape & Crescent & Oval \\
& - Length $(\mu \mathrm{m})$ & $10-15$ & $8-13$ \\
& - Number of septat & $3-5$ & Aseptat \\
& b. Microconidia & & \\
& - Shape & Oval & $8-13$ \\
& - Length $(\mu \mathrm{m})$ & $2-5$ & Aseptat \\
\hline
\end{tabular}

Note: $\left.{ }^{*}\right)$ Conidia are not separated into macroconidia or microconidia

C. musae colonies were black with mycelia like a cotton. The shapes of conidia were elips, aseptat (Robles-Yerena et al., 2019) but some of Cladosporium formed septate (Bensch et al., 2012) and rounded at the ends. Conidia were formed in a series on conidiophores. Crous et al. (2005) added that the characteristic of Cladosporium is pigmented conidiophores formed in a series. Fungi C. musae are included in Dothideomycetes class, Capnodiales order and Mycosphaerellaceae family. C. musae belongs to a group of Hyphomycetes as classified by Kiffer and Morelet (1999) with conidia formed in acropetal and often branched chains. Most genera of Hyphomycetes were known as pathogenic fungi, including Fusarium oxysporum.

The average diameter growth of $F$. oxysporum and $C$. musae colonies at nine weeks post isolation reached $4.99 \mathrm{~cm}$ and $4.42 \mathrm{~cm}$, respectively (Figure 2). The two pathogenic colonies almost covered $6 \mathrm{~cm}$ in diameter on agar medium. Hadiwiyono et al. (2013) reported that the average growth of F.oxysporum colonies at eight weeks post isolation reached $5.67 \mathrm{~cm}$. Sitepu et al. (2012) recounted that $F$. oxysporum optimum grew in pure cultures with a $\mathrm{pH}$ range of 3.6-8.4 
and supported the sporulation requiring an optimum $\mathrm{pH}$ of 5.

The optimum temperature of pathogenic fungi growth was recorded between $27^{\circ} \mathrm{C}$ and $30^{\circ} \mathrm{C}$ in the incubation chamber. Several reports indicated that $C$. musae growth was sensitive to the changes in temperature. Conidia of $C$. musae could be germinated at the temperatures of
22-34 ${ }^{\circ} \mathrm{C}$ (Sahlan, 2003). Aihara et al. (2002) confirmed that fungi could produce spores with a temperature of $5-36^{\circ} \mathrm{C}$. PDA cultured medium with a $\mathrm{pH}$ range of 4-6 supported the growth of pathogens. The diameter of the fungus of the genus Cladosporium usually increased in 28 days post incubation (Aihara et al., 2001).

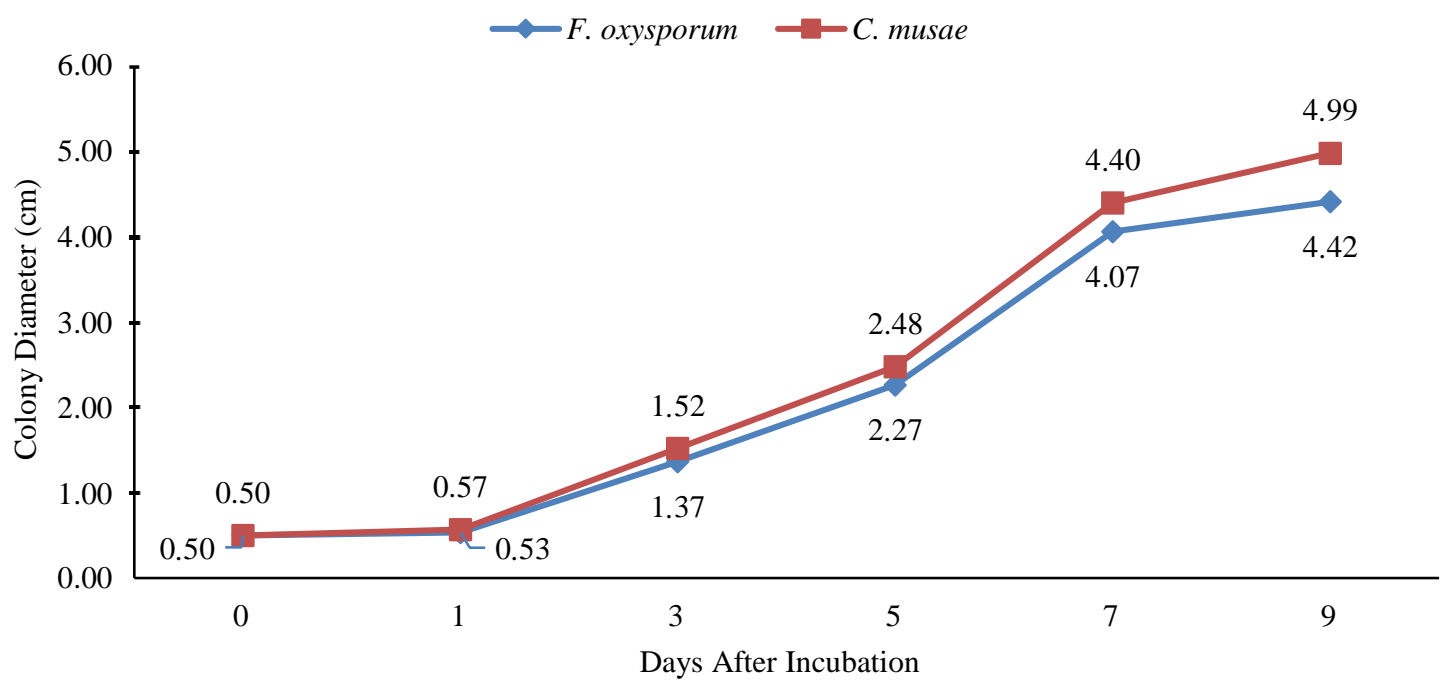

Figure 2. Colony growth of pathogenic fungi in agar medium

\section{CONCLUSIONS}

Non-quarantine pests identified in this study include Fusarium oxysporum causing fusarium wilt and Cladosporium musae causing leaf speckle. Pathogens attacked banana plantations in Morotai Island simultaneously by showing particular symptoms of wilting and spotting. The pathogen causing leaf spot (Mycosphaerella fijiensis) as a target of quarantine pest was not found in this research.

\section{ACKNOWLEDGEMENT}

The authors thanks to Salma Lahia and the personnel at The Plantation Department, Regional Agricultural Office of Morotai Island, for the banana technical sampling during the course of the experiment.

\section{REFERENCES}

Abd-Elsalam, K. A., Roshdy, S., Amin, O. E., \& Rabani, M. (2010). First morphogenetic identification of the fungal pathogen Colletotrichum musae (Phyllachoraceae) from imported bananas in Saudi Arabia. Genetics and Molecular Research: GMR, 9(4), 23352342. https://doi.org/10.4238/vol9-4gmr972

Aihara, M., Tanaka, T., \& Takatori, K. (2001). Cladosporium as the main fungal contaminant of locations in dwelling environments. Biocontrol Science, 6(1), 49-52. https:// doi.org/10.4265/bio.6.49

Aihara, M., Tanaka, T., Ohta, T., \& Takatori, K. (2002). Effect of temperature and water activity on the growth of Cladosporium sphaerospermum and Cladosporium cladosporioides. Biocontrol Science, 7(3), 193-196. https://doi.org/10.4265/bio.7.193

Al-Jaradi, A., Al-Mahmooli, I., Janke, R., Maharachchikumbura, S., Al-Saady, N., \& AlSadi, A. M. (2018). Isolation and identification of pathogenic fungi and oomycetes associated with beans and cowpea root diseases in Oman. PeerJ, 6, e6064. https://doi.org/10.7717/peerj. 6064

Amani, M., \& Avagyan, G. (2014). Isolation and identification of fungal pathogens on banana trees (Musa acuminata L.) in Iran. International Journal of AgriScience, 4(8), 
409-413. Retrieved from https://www.cabi. org/ISC/abstract/20153189810

Bensch, K., Braun, U., Groenewald, J. Z., \& Crous, P. W. (2012). The genus Cladosporium. Studies in Mycology, 72, 1-401. https://doi. org/10.3114/sim0003

Booth, C. (1971). The Genus Fusarium. Kew, UK: Commonwealth Mycological Institute.

BPS-Statistics of Maluku Utara Province. (2017). Statistics of horticultural agriculture (vegetables and fruits) of Maluku Utara Province 2017. Ternate: BPS Provinsi Maluku Utara. Retrieved from https://malut.bps.go. id/publication/2018/10/17/260e689371ef50a8 3f424886/statistik-pertanian-hortikultura-sayuran-dan-buah-buahan--provinsi-malukuutara-tahun-2017.html

BPS-Statistics of Maluku Utara Province. (2018). Statistics of horticultural agriculture (vegetables and fruits) of Maluku Utara Province 2018. Ternate: BPS Provinsi Maluku Utara. Retrieved from https://malut.bps.go. id/publication/2019/11/27/0c71921db2c9465b ba27a1b5/statistik-pertanian-hortikultura-sayuran-dan-buah-buahan--provinsi-malukuutara-2018.html

Buddenhagen, I. W. (2009). Understanding strain diversity in Fusarium oxysporum f.sp. cubense and history of introduction of "Tropical Race 4" to better manage banana production. Acta Horticulture, 828, 193-204. Retrieved from https://www.actahort.org/books/828/828_19.h tm

Crous, P. W., Schroers, H. J., Groenewald, J. Z., Braun, U., \& Schubert, K. (2005). Metulocladosporiella gen. nov. for the causal organism of Cladosporium speckle disease of banana. Mycological Research, 110(3), 264275. https://doi.org/10.1016/j.mycres.2005.10. 003

Davis, R. I., Moore, N. Y., \& Fegan, M. (2000). Blood disease and Panama disease: two newly introduced and grave threats to banana production in the island of New Guinea. Proceedings of the Papua New Guinea Food and Nutrition 2000 Conference PNG University of Technology, Lae, 26-30 June 2000'. ACIAR Proceedings No. 99. (Eds RM Bourke, MG Allen, JG Salisbury) pp. 816-821.
(ACIAR: Canberra). Retrieved from https:// espace.library.uq.edu.au/view/UQ:96117

DISTAN, [Dinas Pertanian]. (2018). Banana commodity of Maluku Utara. Ternate: Regional Agricultural Office of Maluku Utara Province Pub.

Edison, H. S., Sutanto, A., Hermanto, C., Uji, T., \& Razak, N. (1997). The exploration of musaceae in Maluku Islands, 18 November 14 December 1996. Montpellier, France: Research Institute for Fruit-INIBAB. Retrieved from http://www.musalit.org/see More.php?id=15057

EPPO, [European and Mediterranean Plant Protection Organization]. (2011). Mycosphaerella fijiensis, distribution maps of plant diseases. Wallingford, UK: CABI. Retrieved from https://www.cabi.org/isc/data sheet $/ 35278$

FAO. (2016). ISPM 16: Regulated nonquarantine pests; concept and application. international standards for phytosanitary measures. Rome: International Plant Protection Convention (IPPC). Retrieved from http://www.fao.org/3/a-y4223e.pdf

Ferraez, L. C., Arango, R. G., Flores, N. E. R., \& Kay, A. C. J. (2008). A simple method to obtain single conidium isolates directly from banana (Musa sp.) leaves infected with Mycosphaerella fijiensis Morelet. Rev Mexica de Fitopatologi, 26(1), 76-78. Retrieved from https://www.redalyc.org/pdf/612/61226112.p df

Hadiwiyono. (2011). Blood bacterial wilt disease of banana: the distribution of pathogen in infected plant, symptoms, and potentiality of diseased tissues as source of infective inoculums. Nusantara Bioscience, 3(3), 112117. Retrieved from https://smujo.id/nb/article /view/958

Hadiwiyono, H., Widyantoro, A., \& Widono, S. (2013). Antagonisme Bacillus terhadap infeksi layu Fusarium pada bibit pisang hasil kultur jaringan. Agrosains: Jurnal Penelitian Agronomi, 15(1), 21-26. https://doi.org/ 10.20961/agsjpa.v15i1.18990

Hendaru, I. H., Hidayat, Y., \& Ramdhani, M. (2017). Karakter morfologi tujuh aksesi pisang dari Maluku Utara. Buletin Plasma Nutfah, 
23(1), 13-22. http://dx.doi.org/10.21082/blpn. v23n1.2017.p13-22.

IAQA, [Indonesian Agricultural Quarantine Agency]. (2018). Quarantine pests list report. Jakarta: IAQA.

Jayatri, H. N., Sumardiyono, C., \& Wibowo, A. (2018). Race and virulence determination of Fusarium oxysporum f. sp. cubense isolates from Sidomulyo Village of Bantul, Yogyakarta. Jurnal Perlindungan Tanaman Indonesia, 22(1), 72-81. https://doi.org/ $10.22146 /$ jpti.26283

Jones, D. R. (2000). Diseases of banana, abaca and enset. Wallingford, $\mathrm{UK}$ : $\mathrm{CAB}$ International. Retrieved from https://scholar. google.com/scholar_lookup?title=Diseases +0 $\mathrm{f}+$ Banana\%2C+Abaca+and+Enset\%2E\&auth or $=$ Jones + D. + R.\&publication_year $=2000$

Kiffer, E., \& Morelet, M. (1999). The deuteromycetes. mitosporic fungi: classification and generic keys. Enfield, New Hampshire, USA: Science Publishers, Inc. Retrieved from https://books.google.co.id/ books?hl=id\&lr=\&id=YUxZDwAAQBAJ\&oi $=$ fnd $\& p g=P P 1 \& d q=$ The + Deuteromycetes $+\mathrm{M}$ itosporic+Fungi:+Classification+and+Generic + Keys\&ots $=$ Rz6eKBU13v\&sig $=x U 3 m e-s i g F$ 1HTiD7klvGn8S8w_U\&redir_esc $=y \# v=o n e p$ age \&q=The\%20Deuteromycetes.\%20Mitospo ric\%20Fungi\%3A\%20Classification\%20and $\% 20$ Generic $\% 20$ Keys \&f=false

Leslie, J. F., \& Summerell, B. A. (2006). The Fusarium laboratory manual. Oxford, UK: Blackwell Publishing Asia. Retrieved from https://www.wiley.com/en-us/The+Fusarium +Laboratory+Manual-p-9780813819198

Martinelli, F., Scalenghe, R., Davino, S., Panno, S., Scuderi, G., Ruisi, P., Villa, P., Stroppiana, D., Boschetti, M., Goulart, L. R., Davis, C. E., Dandekar, A. M. (2014). Advanced methods of plant disease detection. A review. Agronomy for Sustainable Development, 35, 1-25. https://doi.org/10.1007/s13593-014-024 6-1

Nasir, Jumjunidang, \& Riska. (2005). Detection and mapping of Fusarium oxysporum f.sp. cubense on the potential area for banana agribusiness development in Indonesia. Jurnal Hortikultura, 15(1), 50-57. Retrieved from http://ejurnal.litbang.pertanian.go.id/index.ph p/jhort/article/view/961

Nasir, N., Pittaway, P. A., Pegg, K. G., \& Lisle, A. T. (2003). A foliar rating system for comparing the resistance of banana cultivars grown as tissue-cultured plantlets in the laboratory to Fusarium wilt. Australasian Plant Pathology, 32(4), 521-526. https:// doi.org/10.1071/AP03065

Ploetz, R. C. (1988). Vegetative compatibility among races of Fusarium oxysporum f. sp. cubense. Plant Disease, 72, 325-328. https:// doi.org/10.1094/pd-72-0325

Riska, Jumjunidang, \& Hermanto, C. (2012). Confirm status of VCG Fusarium oxysporum f. sp. cubense in West Sumatera, Indonesia. ARPN Journal of Agriculture and Biological Science, 7(4), 244-249. Retrieved from http:// www.arpnjournals.com/jabs/research_papers/ rp_2012/jabs_0412_385.pdf

Robles-Yerena, L., Ayala-Escobar, V., LeyvaMir, S. G., Lima, N. B., Camacho-Tapia, M., \& Tovar-Pedraza, J. M. (2019). First report of Cladosporium cladosporioides causing leaf spot on tomato in Mexico. Plant Pathology, 101, 759. https://doi.org/10.1007/s42161-01800218-x

Sahlan. (2003). Effects of temperature and relative humidity on conidial germination and germ tubes development of Cladosporium musae Mason. Jurnal Hortikultura, 13(3), 197-204. Retrieved from http://ejurnal. litbang.pertanian.go.id/index.php/jhort/article/ view/1197

Samson, R. A., Hoekstra, E. S., \& Frisvad, J. C. (2004). Introduction to food and airborne fungi. Utrecth, Netherlands : Centraalbureau voor Schimmelcultures (CBS). Retrieved from https://www.cabdirect.org/cabdirect/abstract/2 0053187047

Satyanarayana, T., Deshmukh, S. K., \& Johri, B. N. (2017). Development in fungal biology and applied mycology. Singapore: Springerm Verlag. Retrieved from https://www.springer. com/gp/book/9789811047671

Seifert, K. A., \& Gams, W. (2011). The genera of Hyphomycetes - 2011 update. Persoonia, 27, 119-129. https://doi.org/10.3767/003158511 X617435 
Semangun, H. (2007). Horticultural diseases in Indonesia. 2nd Edition. Yogyakarta: Gadjah Mada University Press.

Sitepu, F. E., Lisnawita, Pinem, M. I. (2012). Fusarium wilt (Fusarium oxysporum f.sp. cubense (E.F.Smith) Synd. \& Hans.) on banana (Musa spp.) and its related with Radopholus similis in the field. Jurnal Online Agroekoteknologi, 2(3), 1204-1211. Retrieved from https://media.neliti.com/media/publicati ons/100264-ID-none.pdf

Soesanto, L., Mugiastuti, E., \& Ahmad, F. (2013). Diagnosis lima penyakit utama karena jamur pada 100 kultivar bibit pisang. Jurnal Hama Dan Penyakit Tumbuhan Tropika, 12(1), 3645. Retrieved from http://jhpttropika.fp.unila. ac.id/index.php/jhpttropika/article/view/114

Stover, R. H. (1972). Banana, plantain and abaca diseases. London, UK: Commonwealth Agricultural Bureaux.

Surridge, A. K. J., Wehner, F. C., Crous, P. W., \& Viljoen, A. (2003). First report of Cladosporium musae on banana in South Africa. Australasian Plant Pathology, 32(4), 499-503. https://doi.org/10.1071/AP03051
Tushemereirwe, W. K., Gold, W. K., Speijer, P. R., \& Holderness, M. (2011). Foliar diseases of banana in Uganda: Results from a diagnostic survey. African Crop Science Journal, 1(2), 145-149. https://doi.org/ 10.4314/acsj.v1i2.69904

Wibowo, A., Subandiyah, S., Sumardiyono, C., Sulistyowati, L., Taylor, P., \& Fegan, M. (2011). Occurrence of tropical race 4 of Fusarium oxysporum f. sp. cubense in Indonesia. Plant Pathology Journal, 27(3), 280-284. https://doi.org/10.5423/PPJ.2011.27 .3 .280

Widyantoro, A., Hadiwiyono, \& Subagiya. (2020). Short communication: Biological control of fusarium wilt on banana plants using biofertilizers. Biodiversitas, 21(5), 2119-2123. https://doi.org/10.13057/biodiv/d 210540

Yonow, T., Ramirez-Villegas, J., Abadie, C., Darnell, R. E., Ota, N., \& Kriticos, D. J. (2019). Black Sigatoka in bananas: ecoclimatic suitability and disease pressure assessments. PLoS ONE, 14(8), e0220601. https://doi.org/10.1371/journal.pone.0220601 